\title{
Dietary Effect of Velvet Bean (Mucuna utilis) Leaf Meal on Haematology and Serum Biochemistry of Broiler Finisher Birds
}

\author{
Peter-Damian Chukwunomso Jiwuba ${ }^{1^{*}}$, Emeka Cyril Onunwa ${ }^{2}$ \\ ${ }^{1}$ Department of Animal Health and Production Technology, Federal College of Agriculture, \\ P.M.B.7008, Ishiagu, Ebonyi State, Nigeria. \\ ${ }^{2}$ Department of General Studies, Federal College of Agriculture, P.M.B.7008, Ishiagu, \\ Ebonyi State, Nigeria. \\ Corresponding author: jiwubapc@yahoo.com or jiwubapc@gmail.com
}

Keywords: Mucuna utilis, poultry, alternative feedstuff, blood indices and leaf meal

\begin{abstract}
A study was conducted to investigate the effect of feeding varying levels of Mucuna utilis leaf meal (MULM) on the haematological and serum biochemistry parameters of broiler finisher birds using ninety six four-week-old chicks for 29 days. The birds were randomly assigned to the four treatments, each replicated three times with eight birds constituting a replicate. The birds were allotted to four treatments containing 0,10, 20, and 30\% MULM. The haematological parameters evaluated showed no significant difference $(\mathrm{p}>0.05)$ on PCV, Hb, RBC and WBC. MCHC was improved and better at D birds in comparison to other treatments. MCV and $\mathrm{MCH}$ differ significantly $(p<0.05)$ with birds on control showing higher values than those on $C$ and $D$. Total protein, albumin and globulin showed better $(\mathrm{p}<0.05)$ values for the treatment groups when compared with the control group. The study concluded that, on account of adequate haematocrit and immune status, incorporation of MULM at $30 \%$ in the diets of broiler finisher birds had no deleterious effect on haematological and serum biochemical indices and therefore recommend for production of healthy broilers.
\end{abstract}

\section{Introduction}

Poultry nutritionists aim to formulate diets to enhance the performance of the birds by supplying all the nutrients required for growth, maintenance or any other productive function without compromising the physiological/health status of the birds. The diets should however be formulated at a cheaper rate and at the same time supply the required nutrients without altering the physiological status of the animal. This has necessitated the need for cheaper available alternative feedstuffs like Mucuna utilis leaf meal. Mucuna utilis commonly known as velvet bean is a vigorous annual climbing plant, originated from South Asia and Malaysia, but can grow well in the tropics due to its outstanding adaptability to extreme climatic conditions and disease resistance profile. It has been reported to be rich in energy, protein, amino acids, vitamins and minerals [13], [15], [3], [16]. The plant is known to have multipurpose properties. Its high medicinal [17], [9], [16] and blood boosting [16] properties have been documented. However, the reported anti-nutritional factors like trypsin inhibitors, haemagglutinins, phytic acid, hydrocyanic acid and tannins [13] which abound in Mucuna utilis thrust the blood examination in this study.

Blood parameters are indispensable indicators in measuring the nutritional and health status of humans and animals. They play pivotal role in clinical evaluation, diagnostic and prognostic evaluation of various types of diseases in farm animals. Haematology is the branch of physiology that is concerned with the study of blood, blood-forming organs and blood diseases. The haematological components are helpful in monitoring feed toxicity especially with feed constituents that affect the blood as well as the health status of farm animals [4]. Jiwuba et al. [5] noted the importance of packed cell volume and red blood cells in determining feed toxicity and anemia in farm animals. Serum biochemical parameters tend to have specificity for an organ and/or a limited range of pathological processes. Serum creatinine and total protein help in evaluation of liver and kidney function and diseases while serum urea evaluates renal function [6]. This study is therefore 
designed to determine the effects of different levels of Mucuna utilis leaf meal on the haematology and serum biochemistry of broiler finisher birds.

\section{Materials and Methods}

Experimental site: The experiment was carried out at the Poultry Unit, Federal College of Agriculture, Ishiagu, Ebonyi state, Nigeria. The College is located at about three kilometers $(3 \mathrm{~km})$ away from Ishiagu main town. The College is situated at latitude $5.56^{\circ} \mathrm{N}$ and longitude $7.31^{\circ} \mathrm{E}$, with an average rainfall of $1653 \mathrm{~mm}$ and a prevailing temperature condition of $28.50^{\circ} \mathrm{C}$ and relative humidity of about $80 \%$.

Processing of Mucuna utilis leaf meal (MULM): Freshly succulent leaves of Mucuna utilis without flowers were harvested within the College farms. Thereafter, the leaves were air dried to reduce/eliminate possible anti-nutritional factors present in the fresh leaves for subsequent milling and also to obtain about $10 \%$ moisture content. They were thereafter milled by passing through hammer mill, before been used to formulate the experimental diets.

Experimental Diets: Four experimental diets designated as A, B, C, and D where formulated to contain 0,10, 20,30, levels of MULM. The compositions of the experimental diets are presented in Table 1.

Table 1. Composition of experimental diets.

\begin{tabular}{lcccc}
\hline Ingredients & $\mathbf{A}$ & $\mathbf{B}$ & $\mathbf{C}$ & $\mathbf{D}$ \\
\hline Maize & 54.00 & 52.00 & 50.00 & 47.00 \\
Wheat meal & 17.00 & 10.00 & 6.00 & 2.00 \\
Soyabean meal & 21.50 & 20.50 & 16.50 & 13.50 \\
Mucuna leaf meal & 0.00 & 10.00 & 20.00 & 30.00 \\
Fish meal & 3.00 & 3.00 & 3.00 & 3.00 \\
Bone meal & 3.00 & 3.00 & 3.00 & 3.00 \\
Vitamin/premix & 0.50 & 0.50 & 0.50 & 0.50 \\
Lysine & 0.25 & 0.25 & 0.25 & 0.25 \\
Methionine & 0.25 & 0.25 & 0.25 & 0.25 \\
Common salt & 0.50 & 0.50 & 0.50 & 0.50 \\
\hline Total & $\mathbf{1 0 0}$ & $\mathbf{1 0 0}$ & $\mathbf{1 0 0}$ & $\mathbf{1 0 0}$ \\
\hline
\end{tabular}

*Vitamin and mineral premix contributed the following to each kilogram of diet: vitamin A $500 \mathrm{IU}$; vitamin D $1500 \mathrm{IU}$; vitamin E $3 \mathrm{IU}$; vitamin K $2 \mathrm{mg}$; riboflavin $3 \mathrm{mg}$; pantothenic acid $6 \mathrm{mg}$; niacin $15 \mathrm{mg}$; vitamin B $120.8 \mathrm{mg}$; choline, $3 \mathrm{mg}$; folic acid $4 \mathrm{mg}$; manganese $8 \mathrm{mg}$; zinc $0.5 \mathrm{mg}$; iodine $1.0 \mathrm{mg}$; Co $1.2 \mathrm{mg}$.

Experimental Animal and Management: Ninety six four-week-old chicks were used for this experiment. They were randomly assigned to the four treatments, each replicated three times with eight birds constituting a replicate. The four treatment groups were fed the four experimental diets in a Completely Randomized Design for 29 days. Each replicate was housed in a concrete floor covered with wood shavings as the litter material. The chicks were weighed using digital sensitive balance and randomly distributed accordingly. The chicks were reared in a deep litter system whose floor was covered with wood shavings at about $5 \mathrm{~cm}$ depth. Sufficient management conditions like floor space, light, temperature, ventilation and relative humidity were provided to each of the groups. The chickens were vaccinated against major poultry viral and bacterial diseases as per the recommended vaccination schedule. During the experimental period, they were fed ad libitum on replicate basis and provided with clean and wholesome water. 
Blood profile analysis: Blood samples $(5 \mathrm{ml})$ were drawn from three birds per replicate on the last day of the study. The birds were bled through the marginal wing vein. The samples were separated into two lots and used for biochemical and haematological studies. An initial $2.5 \mathrm{ml}$ was collected from each sample in labelled sterile universal bottle containing $1.0 \mathrm{mg} / \mathrm{ml}$ ethyldiamine tetracetic acid and used for haematological analysis. Another $2.5 \mathrm{ml}$ was collected over anti-coagulant free bottle. The blood was allowed to clot at room temperature and serum separated by centrifuging within three hours of collection. Serum biochemistry and haematological parameters were measured using Beckman Coulter Ac-T10 Laboratory Haematology Blood Analyzer and Bayer DCA 2000+ HbAlc analyzer, respectively. Mean cells haemoglobin $(\mathrm{MCH})$, mean cell volume (MCV) and mean cell haemoglobin concentrations $(\mathrm{MCHC})$ were calculated.

Statistical Analysis: The results were analysed using the Statistical Package for Social Sciences (SPSS 17.0). One - way analysis of variance was employed to determine the means and standard error. Differences between means were separated by Duncan Multiple Range Test (Duncan, 1955).

\section{Results and Discussion}

The haematological parameters of broiler finishers fed varying levels of Mucuna utilis leaf meal is presented in Table 2. The results showed no significant effect $(p>0.05)$ on PCV, RBC, Hb, and WBC between the control and the treatment groups. This is an indication that MULM is not toxic to the blood formation and immune system of the birds and hence has no deleterious effects on the broiler finishers. The values fall within the normal physiological range for healthy broilers as reported by Mitruka and Rawnsley [10]. This is an indication that MULM is nutritionally adequate for broiler finishers. However, $\mathrm{MCHC}, \mathrm{MCH}$ and $\mathrm{MCV}$ were significantly $(\mathrm{p}<0.05)$ influenced by the treatment diets. $\mathrm{MCHC}, \mathrm{MCH}$ and $\mathrm{MCV}$ fall within the normal reported by Mitruka and Rawnsley [10] and Johnson-Delaney [8] for broilers. The red blood cell differentials could reflect anaemic condition. The normal range found in this study for the birds gave a clear indication of the absence of anaemia among the experimental groups. The result of this study is in agreement with the results of Sese et al. [12] for growing rabbits fed MULM. This may be attributed to the blood boosting properties of Mucuna utilis as reported by Ujowundu et al. [16]. This showed that MULM had no adverse effect on erythropoiesis and is an indication that the diet did not cause nutrient restriction.

Table 2. Haematological indices of broiler finisher bird fed Mucuna utilis leaf meal.

\begin{tabular}{|c|c|c|c|c|c|}
\hline Parameters & $\mathbf{A}$ & B & $\mathbf{C}$ & D & SEM \\
\hline $\operatorname{PCV}(\%)$ & 28.67 & 29.67 & 27.67 & 29.00 & 0.42 \\
\hline $\mathrm{Hb}(\mathrm{g} / \mathrm{d} 1)$ & 9.70 & 9.97 & 9.40 & 9.77 & 0.45 \\
\hline $\operatorname{RBC}\left(\times 10^{12} / 1\right)$ & 3.31 & 3.62 & 3.52 & 3.64 & 0.08 \\
\hline $\mathrm{MCHC}(\%)$ & $33.59^{\mathrm{b}}$ & $33.73^{b}$ & $34.10^{\mathrm{ab}}$ & $34.29^{\mathrm{a}}$ & 0.12 \\
\hline MCH (pg) & $29.39^{\mathrm{a}}$ & $27.47^{\mathrm{ab}}$ & $26.70^{\mathrm{b}}$ & $26.79^{\mathrm{b}}$ & 0.44 \\
\hline $\operatorname{MCV}(f)$ & $86.75^{\mathrm{a}}$ & $81.84^{\mathrm{ab}}$ & $78.56^{\mathrm{b}}$ & $78.09^{b}$ & 1.13 \\
\hline $\mathrm{WBC}\left(\mathrm{x} 10^{12} / 1\right)$ & 10.80 & 12.70 & 9.00 & 11.50 & 0.68 \\
\hline
\end{tabular}

${ }^{a}, b$ Means within the same row with different superscripts are significantly different $(p<0.05)$

The serum biochemical indices of broiler finishers fed Mucuna utilis leaf meal is presented in Table 3. The result showed significant $(p<0.05)$ difference for total protein, albumin and globulin. Total serum protein range of $26.60-34.30 \mathrm{~g} / 1$ is comparable with the reported values of 27.38-31.0g/1 [14] for broilers. High total protein could be attributed to good protein reserve, thus reflecting the ability of the chickens to store protein for tissue development. This is in agreement with Muhammad et al. [11], who attributed increased serum protein in broilers to dietary inclusion of velvet bean. The serum albumin $(17.10-20.80 \mathrm{~g} / \mathrm{l})$ obtained in this study is in agreement with the reported range of $17.00-28.00 \mathrm{~g} / 1$ by Aderinola et al. [1] for broilers. Jiwuba et al. [6-7] attributed 
serum albumin to liver functioning. Hence the higher albumin reported in this study for the treatment groups may indicate a better liver functioning to the birds fed the respective diets. Ujowundu et al. [16] however reported that the leaf extract of Mucuna utilis are used to reduce high concentration of some anti-nutritional constituents in the body; thus a liver functioning property of Mucuna utilis leaves. Serum globulin was lowest in birds on the control diet in comparison with other treatment groups. This may suggest high immune response and sufficient antibody production as a result of diets containing Mucuna utilis leaf meal. Warrier et al. [17] and Manjunatha et al. [9] earlier reported the medicinal and antibacterial properties of M.utilis plant parts. Urea, creatinine and cholesterol were not $(\mathrm{p}>0.05)$ influenced by the treatment diets. The non-significance $(\mathrm{p}>0.05)$ reported for rea and creatinine implies that the diets had similar effects on the kidney of the broiler finishers across the dietary treatments. This demonstrated the nutritional adequacy of MULM on broiler birds. Similarly, the cholesterol similarities $(\mathrm{p}>0.05)$ obtained in this study may imply normal fat metabolism; an indication of health benefit of incorporating MULM in the diets of finisher broilers.

Table 3. Serum biochemical indices of broiler finishers fed Mucuna utilis leaf meal.

\begin{tabular}{lccccc}
\hline Parameters & A & B & C & D & SEM \\
\hline Total protein $(\mathrm{g} / \mathrm{l})$ & $26.60^{\mathrm{c}}$ & $34.30^{\mathrm{a}}$ & $33.10^{\mathrm{ab}}$ & $29.10^{\mathrm{b}}$ & 0.09 \\
Albumin $(\mathrm{g} / \mathrm{l})$ & $17.10^{\mathrm{b}}$ & $19.50^{\mathrm{a}}$ & $20.80^{\mathrm{a}}$ & $19.60^{\mathrm{a}}$ & 0.34 \\
Globulin $(\mathrm{g} / \mathrm{l})$ & $9.30^{\mathrm{b}}$ & $14.70^{\mathrm{a}}$ & $12.00^{\mathrm{ab}}$ & $11.97^{\mathrm{ab}}$ & 0.46 \\
Urea $(\mathrm{Mg} / \mathrm{dI})$ & 4.30 & 4.71 & 4.87 & 3.53 & 0.20 \\
Creatinine $(\mathrm{Mg} / \mathrm{dI})$ & 0.20 & 0.18 & 0.19 & 0.19 & 0.70 \\
Cholesterol $(\mathrm{Mg} / \mathrm{dI})$ & 97.68 & 95.26 & 103.87 & 108.27 & 2.86 \\
\hline
\end{tabular}

${ }^{\mathrm{a}-\mathrm{c}}$ Means within the same row with different superscripts are significantly different $(\mathrm{p}<0.05)$

\section{Conclusion}

The results of this study revealed that finisher broilers can be fed with up to 30\% MULM in their diets without any detrimental effect on the haematology and serum biochemical indices. MULM could therefore be recommended for finisher broiler production for enhanced blood formation and better immune response.

\section{References}

[1] O.A. Aderinola et al., Utilization of Moringa oleifera leaf as feed supplement in broiler diet, International Journal of Food, Agriculture and Veterinary Sciences. 3(3) (2013) 94-102.

[2] D.B. Duncan, Multiple range test and multiple F-test, Biometrics. 1 (1955) 1-42.

[3] O.O. Emenalon, I.C. Nwachukwu, Effect of calcium hydroxide soaked and cooked velvet beans (Mucuna pruriens) on performance of finisher broilers, Nig. J. Anim. Prod. 33(1) (2006) 53-57.

[4] N.N. Etim et al., Haematological parameters: indicators of the physiological status of farm animals, British J. Sci. 10(1) (2013) 33-45.

[5] P.C. Jiwuba et al., Feed intake, body weight changes and haematology of West African dwarf goats fed dietary levels of Moringa oleifera leaf meal, Agricultura. 13(1-2) (2016) 71-77.

[6] P.C. Jiwuba et al., Blood profile of West African Dwarf goats fed provitamin A cassava peelcentrosema leaf meal based diets, Analele Stiintifice ale Universitatii Alexandru Ioan Cuza din Iasi. Sectiunea II A, Genetica si Biologie Moleculara. 17(3) (2016) 127-134. 
[7] P.C. Jiwuba et al., Haematological and serum biochemical indices of weaner rabbits fed varying levels of dried Gmelina arborea leaf meal, International Blood Research and Reviews. 6(2) (2016) 1-8.

[8] C.A. Johnson-Delaney, Exotic companion medicine handbook for veterinarians, Winger, Lake Worth Florida, 1996.

[9] B.K. Manjunatha et al., Studies on the antibacterial activity of Mucuna monosperma DC, Indian Drugs. 43 (2006) 150-152.

[10] B.M. Mitruka, H.M. Rawnsley, Chemical biochemical and haematological references, values in normal experimental animal. Mason publishing, USA Inc. N.V, 1977, pp. 88-142.

[11] I.A. Muhammad et al., Studies on haematology and serum biochemistry of broiler chickens finished on an unprocessed and processed velvet bean (Mucuna Pruriens (L.)) as dietary protein sources, Biokemistri. 27(2) (2015) 68-75.

[12] B.T. Sese, M. Okpeku, A. Igirigi, Impact of tropical velvet bean (Mucuna Utilis) leaf meal on performance, organ weight and haematological indices of young rabbits, J. Anim. Sci. Adv. 4(4) (2014) 777-786.

[13] P. Siddhuraju, K. Vijayakumari, K. Janardhanan, Chemical composition and protein quality of the little known legume, velvet bean (Mucuna pruriens (L) DC.), J. Agric. Food Chem. 44(9) (1996) 2636-2641.

[14] Z. Steiner et al., Effect of dietary protein/energy combinations on male broiler breeder performance, Acta agriculturae Slovenica. 2 (2008) 107-115.

[15] A.B.I. Udedibie, C.R. Carlini, Crack and cook. A simple and quick process for elimination of concanavalin A (Con A) from Canavalia seeds, Anim. Feed Sci. Tec. 74(2) (1998) 179-184.

[16] C.O. Ujowundu et al., Evaluation of the chemical composition of Mucuna utilis leaves used in herbal medicine in South-Eastern Nigeria, Afr. J. Pharm. Pharmacol. 4(11) (2010) 811-816.

[17] P.K. Warrier, V.P.K. Nambiar, C. Ramankutty, Indian medicinal plants, a compendium of 500 species, Vol. 4, Orient Longman Limited, Madras, India, 1996. 